\title{
Nurse-managed education: the effectiveness of secondary prevention after acute coronary syndromes and the prevalence and predictors of dropout from a cardiac rehabilitation programme
}

\author{
Agnieszka Sławska ${ }^{1}$ Zbigniew Siudak ${ }^{2}$ \\ ${ }^{1}$ Department of Invasive Cardiology, Ostrowiec Świętokrzyski, Poland \\ ${ }^{2}$ Department of Internal Medicine, Collegium Medicum, Jan Kochanowski University, Kielce, Poland
}

Adv Interv Cardiol 2021; 17, 1 (63): 46-53

DOI: https://doi.org/10.5114/aic.2021.104767

\begin{abstract}
A bstract
Introduction: Education programmes are now very often used to limit the consequences associated with a steady increase in the incidence of cardiovascular disease. It is important to assess the effectiveness of these programmes and the reasons why people drop out.

Aim: To evaluate the effects of intensive education of patients undergoing acute invasive cardiology procedures compared to the control group (patients educated in a classical way).

Material and methods: Randomized trial. Measurements of body weight and body composition: during hospital stay, at 45 and 180 days after acute coronary syndrome. We used a self-prepared questionnaire, LOR-T and a TANITA BC1000 body composition analyser.

Results: The sample consisted of 73 patients aged 48 to 89 years. Men constituted $58.9 \%$ of the participants. $43.8 \%$ of the respondents appeared for a follow-up visit after 45 days, and after 180 days $32.8 \%$ came. Body weight, body mass index (BMI), and health condition of the patients did not change significantly during the study. $67.1 \%$ of respondents dropped out from the nurse-managed cardiac education programme. People who were in better health, smoking, without comorbidities, having a heart attack, living far from the place of education more often dropped out from follow-up visits.

Conclusions: Patient education proved ineffective. Body weight, BMI, and health condition of the subjects, both at the time of inclusion and during the long-term evaluation, were very unfavourable.
\end{abstract}

Key words: education, prevention, myocardial infarction, nurse, acute coronary syndrome.

Su m m a ry

The main aim of this study was to evaluate the effects of intensive education of patients undergoing invasive cardiology procedures compared to the control group (patients educated in a classical way). The secondary objectives were: (1) assessment of the differences in the outcomes of patient education from the intervention and measurement analysis group (GIA) and the intervention group without measurement analysis (GIB); (2) assessment of the percentage of patients who drop out of active education in the intervention group (GI) and from follow-up visits in general. Patient education proved ineffective. Body weight, body mass index, and health condition of the subjects, both at the time of inclusion and during the long-term evaluation, were very unfavourable.

\section{Introduction}

Percutaneous coronary intervention $(\mathrm{PCl})$ procedures are only the beginning of the treatment of a patient with acute coronary syndrome, which also includes rehabili- tation, education and secondary prevention as well as long-term patient follow-up. Patients after myocardial infarction (MI) should be encouraged and mobilized to modify their lifestyle [1-3].

\section{Corresponding author:}

Agnieszka Sławska, Department of Invasive Cardiology, Ostrowiec Świętokrzyski, Poland, phone: +48 502832011 ,

e-mail: slawska.agnieszka@gmail.com

Received: 7.10.2020, accepted: 19.12.2020. 
Unfortunately, despite the existence of an extensive medical infrastructure, patients are often re-hospitalized for another MI [4-6].

It turns out that patients not only do not change their lifestyle positively, but often do not believe at all in the positive effects of modifying their current lifestyle. They trust in the effectiveness of pharmacotherapy and interventional treatment, neglecting physical activity and diet [7].

In the entire Polish population, a constant increase in the number of people with modifiable cardiovascular risk factors can be observed. According to the authors of the Multicenter National Population Health Survey (WOBASZ), between 2003-2005 and 2013-2014 the prevalence of obesity in Poles increased by 4.1 percentage points (p.p.) (26\% in 2014), hypertension by 6.9 p.p. (42.8\% in 2014), diabetes by 3 p.p. (9.8\% in 2014) and low physical activity by 1.4 p.p. (55.4\% in 2014$)$. The only positive phenomenon was the decline in the number of cigarette smokers (31\% vs. 25\%) [8].

The above cited data, along with the aging of Polish society, make it necessary to consider the issue of a rapid increase in the incidence of cardiovascular diseases in the coming years $[9,10]$. This will entail the necessity to increase the already high financial outlays for the treatment of cardiac patients [9].

The Ministry of Health in Poland, in cooperation with the Polish Cardiac Society, has developed the KOS-infarction programme, the purpose of which is coordinated, comprehensive specialist care for patients after an MI. This programme includes therapy, rehabilitation, as well as education and secondary prevention in patients after acute coronary syndrome (ACS) [11].

Education and secondary prevention are also encouraged by the European Society of Cardiology, the American Heart Association (AHA) and the American College of Cardiology Foundation (ACC) by regularly publishing guidelines on the prevention of cardiovascular diseases $[5,12,13]$.

However, in the light of the previously cited data the question seems justified: is the education of cardiac patients/patients after myocardial infarction effective? Does secondary prevention in people after $\mathrm{MI}$ and $\mathrm{PCI}$ work?

\section{Aim}

The main aim of this study was to evaluate the effects of intensive education of patients undergoing invasive cardiology procedures compared to the control group (patients educated in a classical way). The secondary objectives were: (1) assessment of the differences in the outcomes of patient education from the intervention and measurement analysis group (GIA) and the intervention group without measurement analysis (GIB); (2) assessment of the percentage of patients who drop out of active education in the intervention group (GI) and from follow-up visits in general.

\section{Material and methods}

The study was performed between February 2018 and April 2019 in the Department of Interventional Cardiology GVM Carint in Ostrowiec Świętokrzyski, Poland. The inclusion criteria were: age over 18 years, hospitalization in the Invasive Cardiology Department for ACS, previous PCI (balloon/stent), discharge directly to the home. Informed consent for inclusion in the study was provided by all patients. The approval of the Bioethics Committee at the Świętokrzyska Chamber of Medicine was obtained for the study: "Resolution No. 14/2018 Kielce, 08.02.2018".

A survey method was used with a self-prepared, non-standardised questionnaire and the standardized Life Orientation Test (LOT-R) questionnaire authored by Scheier, Carver and Bridges, adapted from Poprawa and Juczyński [14]. A categorized observation was conducted using the TANITA BC-1000 body composition analyser as a tool [15].

The LOT-R test consisted of 10 statements: 6 which diagnosed the level of dispositional optimism, and 4 buffer statements, which did not affect the result. The truthfulness of each of the statements was assessed by the respondents on a Likert scale, where 0 meant "definitely does not refer to me", and 4 "definitely refers to me". The test result was assessed by counting the points awarded for 6 diagnostic statements. The score for positive statements corresponded to the scale number, while for negative statements, the score was the opposite: $0=4,1=3$, 2 remained unchanged, $3=1,4=0$. The overall test score was on a scale of 0 to 24 points. A score below 13 points is a low level of optimism, and a score above 16 points is a high level, indicating an optimistic attitude [14].

Patients were included in the study around the third day of hospital stay, that is on day 2 after $\mathrm{PCl}$. Patients were randomly assigned to 1 of 2 groups: the intervention group (GI) and control group (GK). Then, people with GI were randomly assigned to the intervention group and measurement analysis (GIA) group and the intervention group without measurement analysis (GIB) (Figure 1).

The analysis of the measurements was understood as the interpretation of the results of the patient's measurements made by TANITA BC 1000 in relation to the health condition of the participant and the applicable standards.

Half of the patients were assigned to the intervention group ( $1^{\text {st }}$ randomization), in which a trained nurse conducted intensive education in the field of diet, physical activity and stimulants. Education was carried out by means of: conversations with the patient and his family, printed materials (leaflets, thematic guides), thematic materials on-line.

Half of the patients from the intervention group ( $1 / 4$ of all subjects -2 nd randomization) analysed the measurement results with the nurse. These patients also received personalized advice on diet and exercise.

Fifty percent of all enrolled patients (GK) followed the classic course of hospitalization and discharge. 


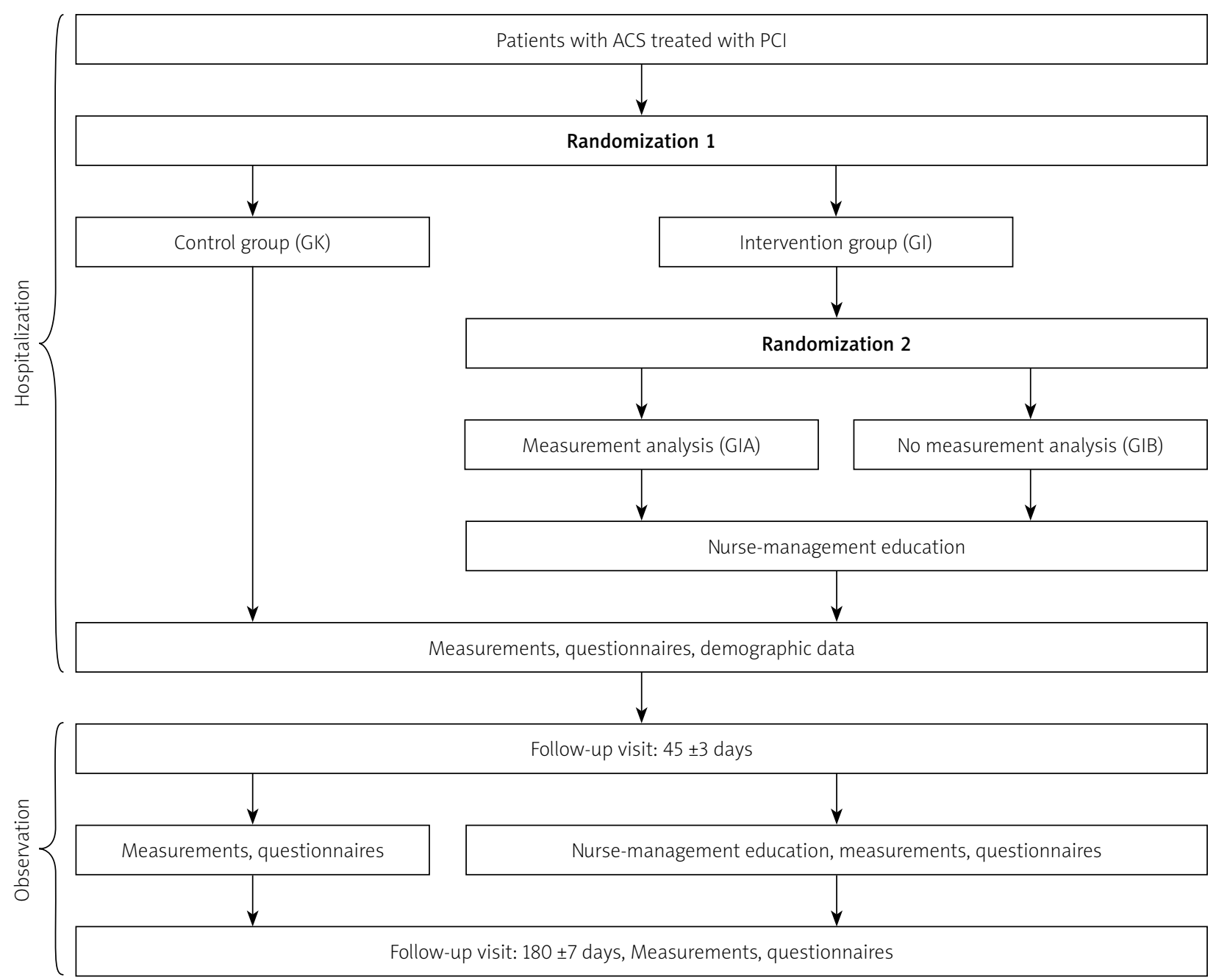

Figure 1. Study flowchart

Follow-up visits were scheduled for 45 and 180 days after patient enrolment. A week before each meeting each patient was contacted by phone to confirm their presence.

For the purposes of this analysis, the effects of education and secondary prevention were defined as: weight loss, body mass index (BMI) decline and improved health condition.

Health condition was assessed as the sum of the following parameters: BMI, percentage of body fat (\%), total body water (\%), physique rating index (independent of weight loss, difference in the proportion of body fat and muscle), metabolic age (age for which a basal metabolic test is appropriate), visceral fat index. Each parameter was assessed on a scale of $0-1$ points. 1 point was awarded for the parameter score within the normal range [15]. A result above or below the norm was given 0 points. The respondents could get a minimum of 0 points and a maximum of 6 points. This scoring assessed the "absolute" level of health condition and was valid for all measurements.
During the next two follow-up visits $\left(2^{\text {nd }}\right.$ and $3^{\text {rd }}$ measurements), the "work on self" performed by the respondents was also assessed. 1 point was awarded for a positive change in a parameter or for no change in a parameter which was correct in the previous measurement. In other cases, the parameter was rated at 0 points. The respondents could get a minimum of 0 points and a maximum of 6 points. The percentage result of this measurement was defined as the "relative" health condition. The difference between the "absolute" and "relative" value of health condition was called the "self-work index" and was measured in percentage points.

\section{Statistical analysis}

Continuous data were described using mean, median, minimum, maximum, standard deviation, and quartiles. Normal distribution was confirmed by the Shapiro-Wilk test. The differences between studied groups were assessed using: $t$-tests, Mann-Whitney $U$ test, Pearson's $\chi^{2}$ test, one-way (ANOVA), Kruskal-Wallis test and Spearman's rank correlation. Values of $p<0.05$ were consid- 
ered statistically significant. The Statistica ver. 13.1 (Tulsa, OK, USA) package was used for analysis.

\section{Results}

The study included 73 patients, aged 48 to 89 years (mean: $68.29 \pm 10.42$ ). On average, the respondents lived (mean: $29.32 \pm 52.24 \mathrm{~km}$ ) from the place where education was provided. The level of dispositional optimism of the respondents ranged from 3 to 24 points (mean: 14.55
土4.06). Detailed characteristics of the study participants are provided in Tables I and II.

$47.95 \%(n=35)$ of all participants in the study decided to drop out of both follow-up meetings. Factors influencing dropout of visits are presented in Table III.

People who withdrew from the first follow-up visit more often:

- From the control group ( $n=38$; Presence: $31.58 \%$ vs. Dropout: $68.42 \% ; p=0.028)$,

Table I. Characteristics of study participants

\begin{tabular}{|c|c|c|c|c|c|c|c|}
\hline \multirow[t]{2}{*}{ Variable } & & \multicolumn{2}{|c|}{ All } & \multicolumn{2}{|c|}{ GI } & \multicolumn{2}{|c|}{ GK } \\
\hline & & $n$ & $\%$ & $n$ & $\%$ & $n$ & $\%$ \\
\hline \multirow[t]{2}{*}{ Sex } & Male & 43 & 58.91 & 18 & 24.66 & 25 & 34.25 \\
\hline & Female & 30 & 41.09 & 17 & 23.29 & 13 & 17.81 \\
\hline \multirow[t]{3}{*}{ ACS type } & STEMI & 36 & 49.32 & 14 & 19.18 & 22 & 30.14 \\
\hline & NSTEMI & 27 & 36.99 & 14 & 19.18 & 13 & 17.81 \\
\hline & $\mathrm{UA}$ & 10 & 13.69 & 7 & 9.59 & 3 & 4.11 \\
\hline \multirow[t]{2}{*}{ Previous MI } & No & 53 & 72.60 & 27 & 36.99 & 26 & 35.62 \\
\hline & Yes & 20 & 27.40 & 8 & 10.96 & 12 & 16.44 \\
\hline \multirow[t]{3}{*}{ Comorbidities } & No & 8 & 10.96 & 2 & 2.74 & 6 & 8.22 \\
\hline & Hypertension & 45 & 61.64 & 23 & 31.51 & 22 & 30.14 \\
\hline & Diabetes mellitus & 21 & 28.77 & 8 & 10.96 & 13 & 17.81 \\
\hline \multirow[t]{2}{*}{ Nicotinism } & No & 48 & 65.75 & 24 & 32.88 & 24 & 32.88 \\
\hline & Yes & 25 & 34.25 & 11 & 16.07 & 14 & 19.18 \\
\hline
\end{tabular}

ACS - acute coronary syndrome, STEMI - ST elevation myocardial infarction, NSTEMI - non-ST elevation myocardial infarction, UA - unstable angina, GI - intervention group, GK - control group.

Table II. Presence at follow-up visits by randomization group

\begin{tabular}{lcccccc} 
Group & \multicolumn{2}{c}{ Hospitalization } & \multicolumn{2}{c}{$\mathbf{1}^{\text {st }}$ follow-up } & \multicolumn{2}{c}{ 2 $^{\text {nd }}$ follow-up } \\
\cline { 2 - 8 } & $n$ & $\%$ & 11 & 15.07 & 6 & $\%$ \\
\hline GIA & 17 & 23.29 & 9 & 12.33 & 8 & 10.96 \\
\hline GIB & 18 & 24.66 & 12 & 16.44 & 10 & 13.70 \\
\hline GK & 38 & 52.05 & 32 & 43.84 & 24 & 32.88
\end{tabular}

GIA - intervention group and measurement analysis, GIB - intervention group without measurement analysis, GK - control group.

Table III. Dropout predictors for both follow-up visits

\begin{tabular}{|c|c|c|c|c|c|c|c|c|}
\hline \multirow{2}{*}{$\begin{array}{l}\text { Predictor } \\
\text { Health condition on } \\
\text { enrolment }\end{array}$} & \multicolumn{2}{|c|}{ All $(n=73)$} & \multicolumn{2}{|c|}{ Participation in visits } & \multicolumn{2}{|c|}{ Dropout } & \multirow{2}{*}{$\frac{\text { Test }}{\text { U M-W }}$} & \multirow{2}{*}{$\frac{P \text {-value }}{0.053}$} \\
\hline & $M=33.79$ & $S D=32.63$ & $M=26.75$ & $\mathrm{SD}=30.64$ & $M=41.48$ & $\mathrm{SD}=33.42$ & & \\
\hline $\begin{array}{l}\text { Health condition on } \\
\text { enrolment }>42 \%\end{array}$ & $28.77 \%$ & $n=21$ & $33.33 \%$ & $n=7$ & $66.67 \%$ & $n=14$ & $\chi^{2}$ & 0.042 \\
\hline Distance from home [km] & $M=29.32$ & $S D=52.24$ & $M=17.14$ & $\mathrm{SD}=22.59$ & $M=42.55$ & $\mathrm{SD}=69.85$ & U M-W & 0.037 \\
\hline $\begin{array}{l}\text { Distance from home } \\
>20 \mathrm{~km}\end{array}$ & $31.51 \%$ & $n=23$ & $20.55 \%$ & $n=15$ & $10.96 \%$ & $n=8$ & $\chi^{2}$ & 0.049 \\
\hline Previous MI & $27.4 \%$ & $n=20$ & $8.22 \%$ & $n=6$ & $19.18 \%$ & $n=14$ & $\chi^{2}$ & 0.021 \\
\hline No comorbidities & $10.96 \%$ & $n=8$ & $1.37 \%$ & $n=1$ & $9.59 \%$ & $n=7$ & $\chi^{2}$ & 0.018 \\
\hline No history of hypertension & $38.36 \%$ & $n=28$ & $13.70 \%$ & $n=10$ & $24.66 \%$ & $n=18$ & $\chi^{2}$ & 0.027 \\
\hline Nicotinism on enrolment & $34.25 \%$ & $n=25$ & $12.33 \%$ & $n=9$ & $21.92 \%$ & $n=16$ & $\chi^{2}$ & 0.048 \\
\hline
\end{tabular}




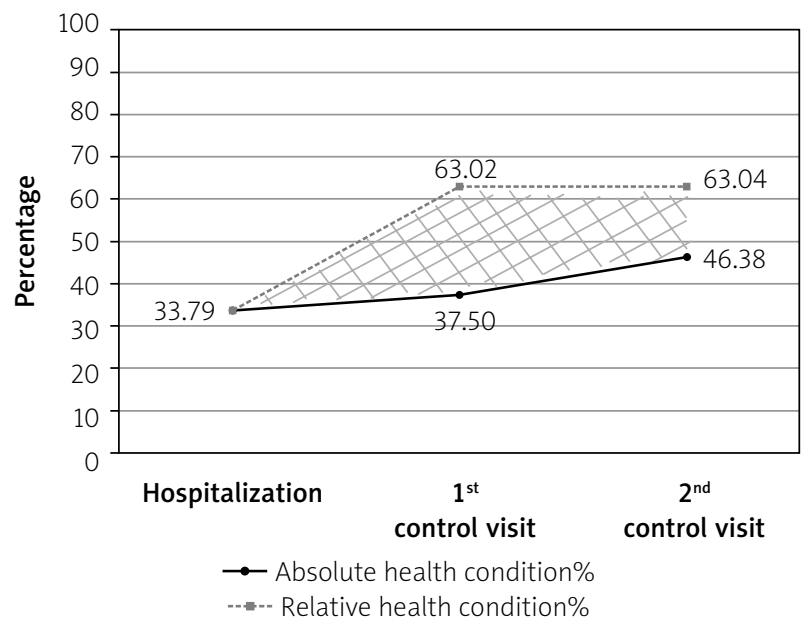

Figure 2. 'Self-work' - performed by all participants during the study

- Having no comorbidities ( $n=8$; Presence: $0.00 \%$ vs. Dropout: $100.00 \% ; p=0.008)$,

- Not suffering from hypertension $(n=28$; Presence: $25.00 \%$ vs. Dropout: $75.00 \% ; p=0.011$ ),

- Smoking on the day of enrolment $(n=25$; Presence: $20.00 \%$ vs. Dropout: $80.00 \% ; p=0.003$ ).

Factors influencing not attending the second follow-up visit were:

- Age (Present: mean $70.51 \pm 9.08$ vs. Dropout: mean $63.75 \pm 10.39 ; p=0.008)$,

- Previous MI ( $n=20$; Present: $5.00 \%$ vs. Dropout: 95.00\%; $p=0.002)$,

Education was offered to 35 people. In the intervention group, $40 \%$ ( $n=14)$ of people completely dropped out of education. Dropout predictors were: previous MI ( $n=8$; Education: $25.00 \%$ vs. Dropout: $75.00 \% ; p=$ $0.021)$, no history of hypertension ( $n=12$; Education: $25.00 \%$ vs. Dropout: $75.00 \% ; p=0.002$ ).
At the first follow-up visit, there were $57.14 \%(n=20)$, and at the second $40.00 \%(n=14)$ of patients from the intervention group. Both visits were more likely to be left by people who had previously had $\mathrm{MI}\left(1^{\text {st }}\right.$ visit: $p=0.037$; $2^{\text {nd }}$ visit: $p=0.009$ ) and had no history of hypertension $\left(1^{\text {st }}\right.$ and $2^{\text {nd }}$ visits: $\left.p=0.006\right)$.

Despite some efforts made by the participants of the study (Figure 2), the education of patients after ACS turned out to be ineffective. None of the effects of education changed significantly over the course of the study (Table IV).

The amount of work done to improve health after hospitalization was influenced by gender and the level of dispositional optimism. Men performed more 'selfwork' (Men: mean $31.06 \pm 22.00$; vs. Women: mean 13.33 $\pm 17.21 ; p=0.036)$ than women. 'Self-work' positively correlated with the level of dispositional optimism ( $R=$ $0.42 ; p=0.017$ ). People with a low level of optimism, on average, performed 'self-work' with the value of mean $18.52 \pm 19.44$ p.p., people with high level of optimism mean $30.30 \pm 17.98$ p.p. No factors significantly influenced the 'self-work' after the first follow-up visit.

The factors significantly influencing the BMI level were not established during the research. It was determined that BMI was not influenced by: age ( $1^{\text {st }}$ visit: $p=0.526 ; 2^{\text {nd }}$ visit: $\left.p=0.319\right)$, $\operatorname{sex}\left(1^{\text {st }}\right.$ visit: $p=0.657 ; 2^{\text {nd }}$ visit: $p=0.508)$, belonging to the intervention group (GI) $\left(1^{\text {st }}\right.$ visit: $p=0.503 ; 2^{\text {nd }}$ visit: $\left.p=0.476\right)$, type ACS ( $1^{\text {st }}$ visit: $p=0.929$; $2^{\text {nd }}$ visit: $\left.p=0.431\right)$, present in history: previous myocardial infarction ( $1^{\text {st }}$ visit: $p=0.499 ; 2^{\text {nd }}$ visit: $p=1.000)$, diabetes ( $1^{\text {st }}$ visit: $p=0.657 ; 2^{\text {nd }}$ visit: $p=0.270$ ), thyroid disorders ( $1^{\text {st }}$ visit: $p=0.502 ; 2^{\text {nd }}$ visit: $p=0.970)$, main source of income $\left(1^{\text {st }}\right.$ visit: $p=0.155 ; 2^{\text {nd }}$ visit: $p=0.122)$, relationships with loved ones ( $1^{\text {st }}$ visit: $p=0.142 ; 2^{\text {nd }}$ visit: $p=0.166$ ), previous physical activity ( $1^{\text {st }}$ visit: $p=0.559 ; 2^{\text {nd }}$ visit: $\left.p=0.378\right)$, nicotinism on

Table IV. Educational outcomes

\begin{tabular}{|c|c|c|c|c|c|c|}
\hline \multirow[t]{2}{*}{ Outcomes } & \multicolumn{2}{|c|}{ Intervention } & \multicolumn{2}{|c|}{ Control } & \multirow[t]{2}{*}{ Test } & \multirow[t]{2}{*}{$P$-value } \\
\hline & Mean & SD & Mean & SD & & \\
\hline \multicolumn{7}{|l|}{ Hospitalization $(n=73)$} \\
\hline Body weight [kg] & 77.26 & 12.45 & 80.06 & 12.77 & $\mathrm{t}$ & 0.351 \\
\hline $\mathrm{BMI}\left[\mathrm{kg} / \mathrm{m}^{2}\right]$ & 28.47 & 4.14 & 28.57 & 3.85 & $\mathrm{t}$ & 0.918 \\
\hline Absolute health condition (\%) & 35.72 & 29.47 & 32.02 & 35.6 & U M-W & 0.309 \\
\hline \multicolumn{7}{|l|}{$1^{\text {st }}$ follow-up visit $(n=32)$} \\
\hline Body weight $[\mathrm{kg}]$ & 79.48 & 12.45 & 78.64 & 15.01 & $\mathrm{t}$ & 0.867 \\
\hline $\mathrm{BMI}\left[\mathrm{kg} / \mathrm{m}^{2}\right]$ & 28.50 & 3.32 & 27.51 & 3.97 & $\mathrm{t}$ & 0.462 \\
\hline Absolute health condition (\%) & 37.50 & 31.00 & 37.50 & 39.0 & U M-W & 0.726 \\
\hline Self-work index (p.p.) & 25.00 & 22.26 & 26.39 & 20.67 & U M-W & 0.969 \\
\hline \multicolumn{7}{|l|}{$2^{\text {nd }}$ follow-up visit $(n=24)$} \\
\hline Body weight [kg] & 80.75 & 11.76 & 83.16 & 14.74 & $t$ & 0.666 \\
\hline $\mathrm{BMI}\left[\mathrm{kg} / \mathrm{m}^{2}\right]$ & 28.93 & 3.35 & 28.50 & 5.11 & $\mathrm{t}$ & 0.807 \\
\hline Absolute health condition (\%) & 46.15 & 32.03 & 46.67 & 43.60 & U M-W & 0.975 \\
\hline Self-work index (p.p.) & 15.39 & 20.93 & 18.33 & 27.72 & U M-W & 0.733 \\
\hline
\end{tabular}

$B M I-b o d y$ mass index 
enrolment ( $1^{\text {st }}$ visit: $p=0.276$; $2^{\text {nd }}$ visit: $p=0.682$ ), disposable optimism ( $1^{\text {st }}$ visit: $p=0.339 ; 2^{\text {nd }}$ visit: $p=0.362$ ), time since previous meeting ( $1^{\text {st }}$ visit: $p=0.845 ; 2^{\text {nd }}$ visit: $p=0.104)$.

Of all the people who reported smoking during study enrolment, 30\% $(n=6)$ attended the follow-up visits. It constituted only $8.22 \%$ of all participants and did not allow for assessing whether nurse-management education influences the breaking of the addiction.

\section{Discussion}

The conducted research shows that body weight, BMI and health condition of the subjects, both at the time of inclusion and during the long term evaluation, were very unfavourable and practically did not change. Nurse management education for patients after MI had no effect on patient outcomes.

However, many researchers believe that education and secondary prevention are effective [16-20].

Michalski et al. reported a decrease in the number of risk factors in educated people [20]. The international EUROASPIRE III study also showed positive effects obtained through secondary prevention (decrease in the number of smokers, improvement of the lipid profile, improved control of drug intake) [18], although the EUROASPIRE $V$ study showed that among CVD patients many lead unhealthy lifestyles and most patients did not achieve the blood pressure, LDL cholesterol and glucose targets [21].

Giannopoulos et al., who conducted a study similar to this one, found a relationship between the education of patients after $\mathrm{MI}$ and the change in the body mass index of the subjects. However, the authors did not want to interpret this result unequivocally, because it was associated not with a decrease in body weight of patients, but only with a lack of an increase in the number of kilograms in the intervention group [22].

In the studies by Pająk et al. education of cardiac patients contributed to an increase in physical activity among patients from the intervention group and caused favourable changes in their diet, which were maintained with long-term (1-year) follow-up. There were no differences in the frequency of smoking, blood pressure, and BMI between the group of patients participating in the education programme and the group subjected to usual care. Nevertheless, changes in the lifestyle of educated people may have contributed to the reduction of their mortality [23].

There is also a group of researchers who claim that (as was the case in this study) education and secondary prevention do not bring the expected results [24-27].

A meta-analysis of the studies performed by Anderson et al. showed no effect of education on mortality in myocardial infarction or on the rate of total revascularization [24]. Brown et al. emphasize the lack of consistent evidence on the influence of education on the incidence of cardiovascular diseases (CVD) or overall mortality [25]. The lack of influence of secondary prevention measures on the final effects (activity, body weight, waist circumference) was also stated by Cohen et al. [28].

The contradiction in the results of the cited studies may result from different end assumptions (final effect, mortality vs. soft effect, change of habits), multiple methods of intervention, and discrepancies in the time spent on conducting the research.

This study did not show a relationship between providing personalized information and recommendations to people after an $\mathrm{MI}$ and a healthier lifestyle by patients. People who received counselling specifically tailored to their health status displayed similar health behaviours to those who received general, non-personalized education. There are no studies that could be referred to in this respect in the literature.

Most researchers (both those who consider education effective and the latter) admit that education and secondary prevention work in unexpected and difficult-to-measure ways.

This is due to little interest of patients in education programmes. As this study has shown, only a minority of patients who have had an Ml choose to participate in a voluntary education programme. Even fewer patients wanted to continue their education after hospitalization. Kotseva et al. also stated that many people do not regularly participate in rehabilitation and education programmes [18]. Similarly, in the research of Meffert et al., the interest in the education programme decreased with the passage of time since the first meeting with the counsellor [19].

Although patients with CVD and after ACS have knowledge resulting from education [29], they do not decide to live according to this knowledge [7, 26, 27, 30].

Therefore, it is difficult to determine whether cardiac education and secondary prevention are effective. For effective actions, there should be standardized methods (form and duration of education, educator's qualifications), the use of which would bring relatively similar results for the entire study population. Meanwhile, the results described in the literature are unpredictably variable. Depending on the research, education works very well, moderately or very poorly. There were also strengths and weaknesses in this study.

The strengths of the study were as follows: Education was conducted by 1 nurse (a common educator for all patients), and the basic printed materials provided to patients were identical. All patients who met the inclusion criteria were eligible to participate in the study. The study is easy to repeat due to the low personnel and financial costs.

Weaknesses of the study: the low number of participants in the study; limited funding - no possibility of conducting additional tests that would encourage patients to attend follow-up visits. 
According to the authors, nursing education did not bring the expected results, because most patients did not want to change their lifestyle and did not want to make the effort to change their habits.

Patients agreed to participate in the study under the influence of emotions accompanying Ml. However, they expected greater profits resulting from participation in the study, including additional medical checks and tests during follow-up visits. The knowledge alone was not enough to motivate them to participate in the follow-up meetings. Knowledge did not produce immediate results. Moreover, educators blamed patients with responsibility for their own health, and it is difficult to deal with the consequences of their behaviour.

Patients who came to the follow-up visits showed a greater interest in knowledge, but in most cases this did not translate into a change in diet and increased physical activity.

The obtained results lead to unpopular conclusions education is not as effective as it is commonly assumed. So it is worth considering in detail the issue of education and secondary prevention, determining how to test their effectiveness and determining the factors that influence this effectiveness.

\section{Conclusions}

Of the enrolled patients, $1 / 2$ did not use the option to attend a follow-up visit to monitor their health condition after an MI if the follow-up was to be performed by a nurse. The meetings were attended more often by patients living in close proximity to the place where education was provided, people with comorbidities and poor health condition, but not smoking and experiencing ACS for the first time. Probably encouraged by the unusual amount of time devoted to them, as well as the materials received, patients from the intervention group appeared at the first arranged meeting more often than those from the control group. It is possible that the education itself disappointed the patients because being a member of the Gl did not affect the presence at the next follow-up visit. Patients who attended the meetings showed some progress in taking care of their health. Unfortunately, these advances were slow and the improvement in health was statistically insignificant.

\section{Conflict of interest}

The authors declare no conflict of interest.

\section{References}

1. Ibanez B, James S, Agewall S, et al. 2017 ESC Guidelines for the management of acute myocardial infarction in patients presenting with ST-segment elevation: The Task Force for the management of acute myocardial infarction in patients presenting with ST-segment elevation of the European Society of Cardiology (ESC). Eur Heart J 2018; 39: 119-77.
2. Neumann FJ, Sousa-Uva M, Alfonso F, et al. Wytyczne ESC/EACTS dotyczące rewaskularyzacji mięśnia sercowego (2018). Kardiol Pol 2018; 76: 1585-664.

3. Roffi M, Patrono C, Collet JP, et al. Wytyczne ESC dotyczące postępowania $w$ ostrych zespołach wieńcowych bez przetrwałego uniesienia odcinka ST w 2015 roku. Kardiol Pol 2015; 73: 1207-94.

4. Ochała A, Siudak Z, Legutko J, et al. Interwencje przezskórne w kardiologii w Polsce w 2014 roku. Raport Zarządu Asocjacji Interwencji Sercowo-Naczyniowych Polskiego Towarzystwa Kardiologicznego (AISN PTK). Kardiol Pol 2015; 73: 672-5.

5. Piepoli MF, Hoes AW, Agewall S, et al. Wytyczne ESC dotyczące prewencji chorób układu sercowo-naczyniowego w praktyce klinicznej w 2016 roku. Kardiol Pol 2016; 74: 821-936.

6. Polonski L, Gasior M, Gierlotka M, et al. A comparison of ST elevation versus non-ST elevation myocardial infarction outcomes in a large registry database: are non-ST myocardial infarctions associated with worse long-term prognoses? Int J Cardiol 2011; 152: 70-7

7. Sawicka K, Łuczyk R, Laska D. Physical activity as a health behavior to reduce the risk of coronary incidents. J Health Sci 2014; 4: 45-68.

8. Drygas W, Bielecki W, Kozakiewicz K, et al. Wieloośrodkowe Ogólnopolskie Badanie Stanu Zdrowia Ludności - WOBASZ. In: Epidemiologia i prewencja chorób układu krążenia. Kopeć G, Jankowski P, Pająk A, Drygas W (eds.). Medycyna Praktyczna, Krakow 2015; 41-56.

9. Fundacja Nutricia. Analiza zmian społeczno-demograficznych oraz wpływu złego odżywiania, niedostatecznej aktywności fizycznej, nałogów i innych czynników ryzyka na rozpowszechnienie oraz koszty cukrzycy i chorób sercowo-naczyniowych w Polsce. Stan obecny i prognoza do 2030 roku. KPMG 2012.

10. World Health Organization. Europejski Raport Zdrowia 2012: Droga do osiągnięcia dobrostanu. Streszczenie. Copenhagen: WHO Regional Office for Europe 2013, 1-21.

11. Sobieszek A, Milewski K. Koordynowana opieka specjalistyczna dla pacjenta po zawale serca - KOS-zawał. Kardiol Inwazyjna 2017; 5: 4-6.

12. Balady GJ, Ades PA, Bittner VA, et al. Referral, enrollment, and delivery of cardiac rehabilitation/secondary prevention programs at clinical centers and beyond: a presidential advisory from the American Heart Association. Circulation 2011; 124: 2951-60.

13. Smith SC, Benjamin EJ, Bonow RO, et al. AHA/ACCF secondary prevention and risk reduction therapy for patients with coronary and other atherosclerotic vascular disease: 2011 update a guideline from the American Heart Association and American College of Cardiology Foundation. Circulation 2011; 124: 2458-73.

14. Juczyński Z. Narzędzia Pomiaru w Promocji i Psychologii Zdrowia. Pracownia Testów Psychologicznych Polskiego Towarzystwa Psychologicznego, Warsaw 2012; 64-6.

15. TANITA. Body Composition Guide for Inner Scan, Medkonsulting, Poznań 2010; 2-7.

16. Ghisi GL, Abdallah F, Grace SL, et al. A systematic review of patient education in cardiac patients: do they increase knowledge and promote health behavior change? Patient Educ Couns 2014; 95: 160-74.

17. Hammill BG, Curtis LH, Schulman KA. Relationship between cardiac rehabilitation and long-term risks of mortality and myocardial infarction among elderly medicare beneficiaries. Circulation 2010; 121: 63-70. 
18. Kotseva K, Wood D, De Backer G, et al.; EUROASPIRE III Study Group. Use and effects of cardiac rehabilitation in patients with coronary heart disease: results from the EUROASPIRE III survey. Eur J Prev Cardiol 2013; 20: 817-26.

19. Meffert C, Gerdes N. Program adherence and effectiveness of a commercial nutrition program: the metabolic balance study. J Nutrition Metabolism 2010; 3: 197656.

20. Michalski P, Kosobucka A, Nowik M, et al. Health education in patients with cardiovascular diseases. Folia Cardiologica 2016; 11: 519-24.

21. Kotseva K, De Backer G, De Bacquer D, et al. Lifestyle and impact on cardiovascular risk factor control in coronary patients across 27 countries: rsults from the European Society of Cardiology ESC-EORP EUROASPIRE V registry. Eur J Prev Cardiol 2019; 26: 824-35.

22. Giannopoulos G, Karageorgiou S, Vrachatis D, et al. Usefulness of a structured adult education program in modifying markers of cardiovascular risk after acute myocardial infarction. Am J Cardiol 2020; 125: 845-50.

23. Pająk A, Wolfshaut-Wolak R, Doryńska A, et al. Longitudinal effects of a nurse-managed comprehensive cardiovascular disease prevention program for hospitalized coronary heart disease patients and primary care high-risk patients. Kardiol Pol 2020; 78: 429-37.

24. Anderson L, Brown JP, Clark AM, et al. Patient education in the management of coronary heart disease. Cochrane Database Syst Rev 2017; 6: CD008895.

25. Brown JPR, Clark AM, Dalal H, et al. Patient education in the management of coronary heart disease. Cochrane Database Syst Rev 2011; 12: CD008895.

26. Chan SS, Leung DY, Wong DC, et al. TH. A randomized controlled trial of stage-matched intervention for smoking cessation in cardiac out-patients. Addiction 2012; 107: 829-37.

27. Kubica A, Andruszkiewicz A, Grześk G, et al. Edukacja zdrowotna jako metoda poprawy realizacji programu terapeutycznego. Folia Cardiologica Excerpta 2010; 5: 93-9.

28. Cohen A, Assyag P, Boyer-Chatenet L, et al. An education program for risk factor management after an acute coronary syndrome: a randomized clinical trial. JAMA Intern Med 2014; 174: 40-8.

29. Siudak Z, Pers M, Dusza K, et al. The efficacy of an educationbased secondary outpatient prevention programme after acute coronary syndrome hospitalisations and treatment in Poland. The Patient Club initiative. Kardiol Pol 2016; 74: 185-91.

30. Buraczyński T, Gotlib J. Ocena wiedzy pacjentów w fazie rekonwalescencji po zabiegu angioplastyki tętnic wieńcowych na temat eliminowania czynników ryzyka choroby wieńcowej jako elementu prozdrowotnego stylu życia. Med Og Nauk Zdr 2014; 20: 199-207. 